Dikirim: 14 Juni 2017 Diterbitkan: 1 Oktober 2017

\section{Penggunaan insektisida dan status kerentanan nyamuk Aedes aegypti di daerah endemis di Kabupaten Purbalingga}

\section{Insecticide use and Aedes aegypti susceptibility status in endemic areas of Purbalingga}

\author{
Slamet Riyadi $^{1}$, Tri Baskoro Tunggul Satoto ${ }^{2}$
}

\section{Abstract}

Purpose: This study aimed to identify the correlation between behavior towards insecticide use and susceptibility status of Aedes aegypti mosquito and to identify the level of mosquito susceptibility from an endemic area in Purbalingga. Methods: This research used a cross-sectional design and was conducted from January 2017 until April 2017 in four endemic villages of Purbalingga. There were 240 respondents involved in the research. Samples from each village were taken using purposive sampling. Ovitraps were installed and interviews were conducted using questionnaires for selected households. Mosquito susceptibility status was described based on the results of WHO's standardized bioassay test. Results: The results of susceptibility test indicated that Aedes aegypti from three endemic villages (Purbalingga Lor, Penaruban, Sempor Lor) were resistant, while mosquitoes from Kembaran Kulon Village were tolerant to cypermethrin $0.05 \%$. Variables correlated with susceptibility status of Aedes aegypti mosquito were respondent's positive attitude $(P R=0.55 ; 0.37-0.80)$ and behavior towards insecticide use ( $P R=1.24 ; 1.05-1.47)$. Conclusions: Misuse of insecticides increased susceptibility status of Aedes aegypti mosquito and becomes the main risk factor for resistance. It is necessary to rotate the insecticide use for programs and households through different modes of action and to provide public health education about insecticide use, selection of active ingredients, dosage, mode of application and periodic replacement of insecticides.

Keywords: susceptibility status; Aedes aegypti; insecticide; behavior

\footnotetext{
${ }^{1}$ Departemen Biostatistik, Epidemiologi, dan Kesehatan Populasi, Fakultas Kedokteran, Universitas Gadjah Mada (Email: mame_lareclp@yahoo.com)

${ }^{2}$ Fakultas Kedokteran Universitas Gadjah Mada
} 


\section{PENDAHULUAN}

Kasus Demam Berdarah Dengue (DBD) di Indonesia meliputi 412 kabupaten/kota dengan Incidence Rate (IR) sebesar 45,85/100.000 penduduk dan Case Fatality Rate (CFR) $0,77 \%$. Secara nasional CFR DBD di Indonesia telah menurun, tetapi di beberapa daerah angka kematian akibat DBD masih tinggi bila dilihat dari angka absolut kematian (1). Dari 35 kabupaten/kota di Jawa Tengah, Kabupaten Purbalingga termasuk wilayah dengan IR DBD yang tinggi melebihi target nasional (>20/100.000 penduduk). Data seksi P2 Dinas Kesehatan Kabupaten Purbalingga menunjukkan IR DBD tahun 2013 (65/100.000 penduduk), tahun 2014 (42/100.000 penduduk), tahun 2015 (27/100.000 penduduk), dan tahun 2016 (30/100.000 penduduk). Secara umum jumlah kasus DBD di Kabupaten Purbalingga tahun 2015-2016 menurun, tetapi dilihat dari angka kefatalan penyakit karena kematian yang disebabkan DBD justru meningkat. Pada tahun 2013 terdapat 3 kasus kematian (CFR 0,5\%), sedangkan pada tahun 2016 terjadi 4 kasus kematian akibat DBD (CFR $2 \%)$.

Berdasarkan stratifikasi wilayah desa endemis, tahun 2014-2016, terdapat 38 desa endemis (15,9\%), dan 18 desa (7,53\%) merupakan high incidence rate (IR $>10$ per 10.000 penduduk) yang diantaranya berada di wilayah Kecamatan Purbalingga dan Kecamatan Kaligondang (2). Hasil analisis masalah kesehatan di Kabupaten Purbalingga tahun 2015, menempatkan program pengendalian DBD sebagai prioritas urutan pertama. Pemerintah daerah dan masyarakat telah melakukan upaya untuk menanggulangi masalah akibat DBD diantaranya pengendalian vektor melalui pemberantasan sarang nyamuk (PSN) 3M plus, abatisasi dan pengendalian menggunakan insektisida. Penggunaan cypermethrin sebagai insektisida tunggal oleh program dinas kesehatan selama 2013-2016 berpotensi menimbulkan resisten karena Aedes aegypti mampu mengembangkan sistem kekebalan terhadap insektisida yang sering digunakan.

Penggunaan insektisida banyak dilakukan di rumah tangga yang dipengaruhi berbagai determinan. Dua faktor yang berperan dalam perubahan perilaku adalah pengetahuan dan sikap (3). Perilaku penggunaan insektisida rumah tangga dengan dosis dan cara tidak tepat dalam jangka waktu lama berpotensi menyebabkan terjadinya resistensi vektor sehingga menurunkan efektivitas insektisida. Penggunaan insektisida secara terus menerus dapat menimbulkan resistensi terhadap serangga sasaran (4). Penelitian ini bertujuan mengetahui status kerentanan nyamuk
Aedes aegypti terhadap insektisida di Kabupaten Purbalingga dan mengetahui hubungan antara perilaku penggunaan insektisida dengan meningkatnya kerentanan nyamuk Aedes aegypti sehingga upaya program pengendalian DBD menjadi lebih efektif.

\section{METODE}

Penelitian explanatory research ini menggunakan rancangan cross-sectional di empat daerah endemis: (Purbalingga Lor, Kembaran Kulon, Penaruban, dan Sempor Lor). Gambaran kerentanan nyamuk diperoleh dari uji bioassay standar WHO. Populasi dalam penelitian ini adalah bangunan rumah di empat desa/kelurahan endemis yaitu di Purbalingga Lor (1376 rumah), Kembaran Kulon (978 rumah), Penaruban (1183 rumah) dan Sempor Lor (306 rumah). Penentuan besar sampel menggunakan pedoman survei entomologi DBD. Mula-mula dihitung jumlah total rumah di tiap desa/kelurahan penelitian, kemudian diperoleh data house index terbaru dari dinas kesehatan dan dicocokkan dengan tabel penentuan besar sampel dalam survei jentik Aedes aegypti (5).

Tabel 1 Jumlah rumah diperiksa untuk mendeteksi telur Aedes aegypti

\begin{tabular}{|c|c|c|c|}
\hline \multirow{2}{*}{$\begin{array}{l}\text { Jumlah rumah } \\
\text { yang berada } \\
\text { di lokasi }\end{array}$} & \multicolumn{3}{|c|}{$\begin{array}{c}\text { Indeks } \\
\text { Rumah sesungguhnya }\end{array}$} \\
\hline & $>1 \%$ & $>2 \%$ & $>5 \%$ \\
\hline 100 & 95 & 78 & 45 \\
\hline 200 & 155 & 105 & 51 \\
\hline 300 & 189 & 117 & 54 \\
\hline 400 & 211 & 124 & 55 \\
\hline 500 & 225 & 129 & 56 \\
\hline 1000 & 258 & 138 & 57 \\
\hline 2000 & 277 & 143 & 58 \\
\hline 5000 & 290 & 147 & 59 \\
\hline 10000 & 294 & 148 & 59 \\
\hline Tak terbatas & 299 & 149 & 59 \\
\hline
\end{tabular}

Jumlah rumah tangga yang menjadi sampel penelitian di Kelurahan Purbalingga Lor (57 rumah), Kelurahan Kembaran Kulon (57 rumah), Desa Penaruban (57 rumah), dan Desa Sempor Lor (54 rumah). Total rumah tangga di tiap desa/kelurahan dibulatkan menjadi 60 rumah, sehingga jumlah total bangunan rumah yang menjadi sampel adalah 240 rumah tangga. Data bangunan rumah dari desa atau kelurahan digunakan untuk menentukan rumah yang akan disurvei, dimulai dari rumah yang pernah terdapat kasus DBD dalam kurun waktu tahun 2015-2016, kemudian dipilih rumah lain secara berselang sampai radius 100 meter ke arah timur, barat, selatan dan utara. 
Nyamuk Aedes aegypti diambil dari rumah tangga yang terpilih dalam fase telur. Setiap rumah tangga terpilih dipasang ovitrap di dalam dan di luar rumah dan dilakukan wawancara terstruktur terhadap anggota keluarga dengan menggunakan kuesioner. Kriteria inklusi responden adalah anggota keluarga dewasa (sudah menikah dan atau telah berumur 18 tahun) serta mampu berkomunikasi dengan surveyor, dan tinggal di rumah tersebut. Kriteria eksklusi dalam penelitian ini adalah responden yang menderita cacat fisik (tuna rungu dan tuna wicara), cacat mental, atau lanjut usia yang sudah tidak bisa berkomunikasi dengan baik dan tidak ada asisten rumah tangga (ART) pengganti. Pemeliharaan koloni nyamuk, identifikasi, dan pengujian bioassay standar WHO dilakukan di laboratorium parasitologi FK UGM.

Variabel independen dalam penelitian ini meliputi pengetahuan, sikap dan perilaku. Pengetahuan merupakan pengetahuan tentang pengendalian vektor DBD, penggunaan insektisida and dampaknya. Sikap merupakan kecenderungan responden memilih setuju atau tidak setuju penggunaan insektisida. Sikap positif adalah kecenderungan tindakan responden yang menyenangi penggunaan insektisida, sedangkan sikap negatif adalah kecenderungan tindakan responden untuk menjauhi, menghindari, atau tidak menyukai penggunaan insektisida. Variabel perilaku merupakan praktek penggunaan insektisida.

\section{HASIL}

Gambaran lokasi penelitian. Gambar 1 menunjukkan pemasangan ovitrap di Purbalingga Lor dilakukan di lima dusun. Pada tahun 2015-2016 terdapat 16 rumah tangga dengan kasus DBD, dengan sebaran terbanyak di Blumbang dan Kecepit.

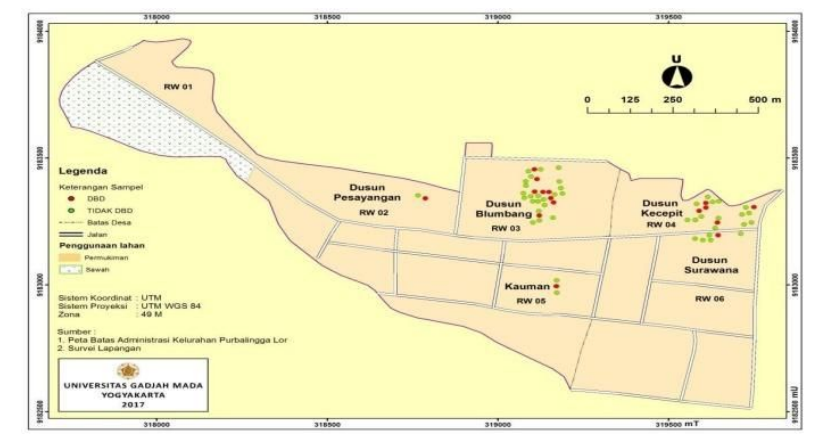

Gambar 1 Distribusi rumah tangga sebagai responden dan tempat pemasangan ovitrap di kelurahan Purbalingga Lor
Dari pemasangan ovitrap di Purbalingga Lor didapatkan 40 rumah $(66,6 \%)$ positif berisi telur nyamuk. Lokasi rumah tangga yang menjadi responden dan dipasang ovitrap di Kelurahan Kembaran Kulon disajikan pada Gambar 3.

Tahun 2015-2016 terdapat 18 rumah tangga kasus DBD dengan sebaran terbanyak di Kembaran dan Sirongge Wetan. Dari pemasangan ovitrap didapatkan 31 rumah (51,6\%) positif terdapat telur nyamuk (Gambar 2).

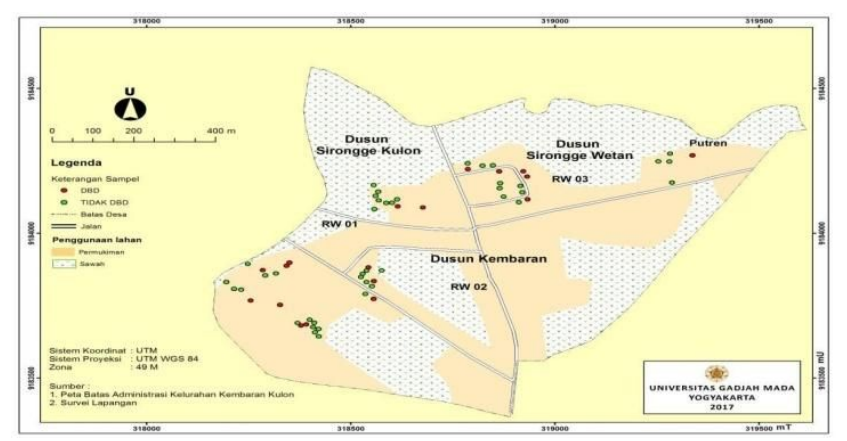

Gambar 2 Distribusi rumah tangga sebagai responden dan tempat pemasangan ovitrap di kelurahan Kembaran Kulon

Gambar 3 menunjukkan pemasangan ovitrap di Penaruban dilakukan di dua dusun. Tahun 2015-2016 terdapat 14 rumah tangga dengan kasus DBD yang sebarannya merata di dua dusun tersebut. Dari pemasangan ovitrap didapatkan 37 rumah (61,6\%) positif terdapat telur nyamuk. Lokasi rumah tangga yang menjadi responden dan dipasang ovitrap di Desa Sempor Lor disajikan pada Gambar 5.

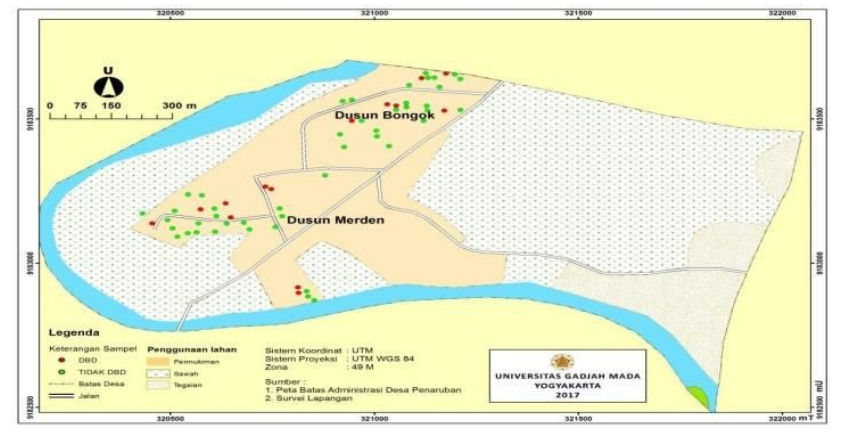

Gambar 3 Distribusi rumah tangga sebagai responden dan tempat pemasangan ovitrap di desa Penaruban

Gambar 4 menunjukkan pemasangan ovitrap di Sempor Lor Tahun 2015-2016 terdapat 25 rumah tangga dengan kasus DBD dengan sebaran terbanyak di Sempor dan Dukuh. Dari pemasangan ovitrap di Sempor Lor didapatkan 42 rumah (70\%) positif terdapat telur nyamuk. 


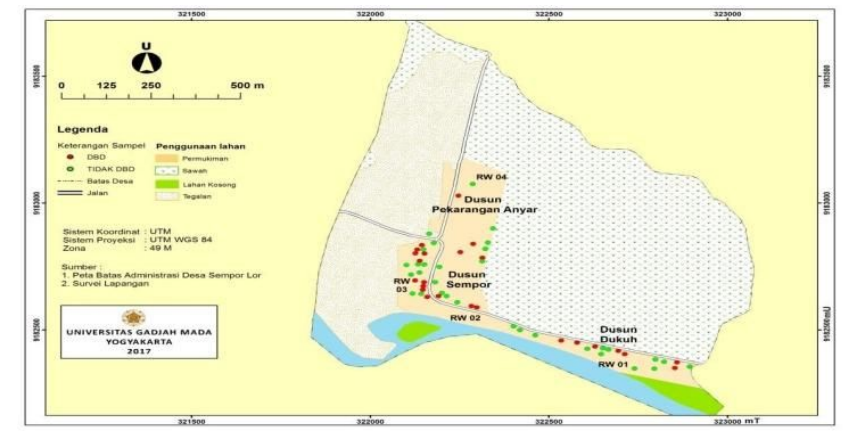

Gambar 4 Distribusi rumah tangga sebagai responden dan tempat pemasangan ovitrap di desa Sempor Lor
Jumlah responden sebanyak 240 rumah tangga yang berasal dari empat desa/kelurahan. Responden lebih banyak berjenis kelamin perempuan (65,83\%). Kelompok umur responden terbanyak pada rentang umur 41-50 tahun (29,58\%). Tingkat pendidikan terakhir responden sebagian besar tamat SMA (27,92\%), dan pekerjaan responden paling banyak merupakan ibu rumah tangga (44,17\%). Karakteristik pengetahuan sikap dan perilaku responden penelitian disajikan pada Tabel 2 .

Tabel 2 Pengetahuan, sikap, dan perilaku responden tentang insektisida

\begin{tabular}{|c|c|c|c|c|c|c|c|c|c|c|}
\hline \multirow{2}{*}{ Variabel } & \multicolumn{4}{|c|}{ Purbalingga Lor Kembaran Kulon } & \multicolumn{2}{|c|}{ Penaruban } & \multicolumn{2}{|c|}{ Sempor Lor } & \multicolumn{2}{|c|}{ Total } \\
\hline & $\mathbf{n}$ & $\%$ & $\mathbf{n}$ & $\%$ & $\mathbf{n}$ & $\%$ & $\mathbf{n}$ & $\%$ & $\mathbf{n}$ & $\%$ \\
\hline \multicolumn{11}{|l|}{ Tingkat pengetahuan } \\
\hline Baik & 50 & 83,33 & 46 & 76,67 & 45 & 75,00 & 47 & 78,33 & 188 & 78,33 \\
\hline Kurang & 10 & 16,67 & 14 & 23,33 & 15 & 25,00 & 13 & 21,67 & 52 & 21,6 \\
\hline \multicolumn{11}{|l|}{ Sikap } \\
\hline Positif & 5 & 8,33 & 19 & 31,67 & 7 & 11,67 & 3 & 5,00 & 34 & 14,17 \\
\hline Negatif & 55 & 91,67 & 41 & 68,33 & 53 & 88,33 & 57 & 95,00 & 206 & 85,83 \\
\hline \multicolumn{11}{|l|}{ Perilaku } \\
\hline Menggunakan insektisida & 33 & 55,00 & 28 & 46,67 & 42 & 70,00 & 45 & 75,00 & 148 & 61,67 \\
\hline Tidak menggunakan insektisida & 27 & 45,00 & 32 & 53,33 & 18 & 30,00 & 15 & 25,00 & 92 & 38,33 \\
\hline
\end{tabular}

Deskripsi subjek penelitian. Tabel 2 menunjukkan 78,33\% responden memiliki tingkat pengetahuan yang baik tentang pengendalian DBD, insektisida dan dampak penggunaan insektisida. Penilaian kriteria pengetahuan responden menggunakan skala kualitatif (6). Sikap negatif terhadap penggunaan insektisida dimiliki 85,83\% responden. Metode pengukuran sikap menggunakan skala likert (method of summated ratings) (7). Pemakaian insektisida dalam bentuk obat anti nyamuk digunakan oleh 148 responden (61,67\%), yang sebagian besar menggunakan satu macam insektisida (85,81\%). Jenis insektisida rumah tangga yang paling banyak digunakan berupa obat anti nyamuk bakar (47,97\%). Bahan aktif insektisida terbanyak synthetic pyrethroids (86,49\%). Responden yang menggunakan insektisida $\geq 2$ Tahun (67,57\%) dengan frekuensi penggunaan setiap hari (75\%) dan dilakukan pada malam hari (98,65\%). Responden yang tidak mengganti insektisida rumah tangga yang digunakannya sebesar 76,35\%.

Dinas Kesehatan Kabupaten Purbalingga menggunakan insektisida Cinoff tahun 2013 dan menggunakan Zeta 15 UL tahun 2015. Kedua insektisida itu berbahan aktif cypermethrin. Frekuensi fogging oleh Dinas Kesehatan Kabupaten Purbalingga di empat desa lokasi penelitian disajikan pada Tabel 3. Tabel 3 menunjukkan bahwa Desa Penaruban paling banyak melakukan fogging dan Kembaran kulon sama sekali tidak pernah melakukan fogging. Bahan aktif insektisida rumah tangga yang banyak digunakan responden adalah d.aletrin $(33,78 \%)$ dan transflutrin (29,73\%).

Tabel 3. Frekuensi kegiatan fogging di desa/kelurahan lokasi penelitian

\begin{tabular}{lcccc}
\hline \multirow{2}{*}{ Desa/Kelurahan } & \multicolumn{4}{c}{ Tahun } \\
\cline { 2 - 5 } & $\mathbf{2 0 1 3}$ & $\mathbf{2 0 1 4}$ & $\mathbf{2 0 1 5}$ & $\mathbf{2 0 1 6}$ \\
\hline Purbalingga Lor & 2 & 0 & 2 & 4 \\
Kembaran Kulon & 0 & 0 & 0 & 0 \\
Penaruban & 4 & 4 & 4 & 0 \\
Sempor Lor & 0 & 2 & 2 & 2 \\
\hline \multicolumn{2}{l}{ Sumber: Seksi P2 Dinas Kesehatan Kabupaten Purbalingga }
\end{tabular}

Pengujian kerentanan nyamuk dengan menggunakan cypermethrin 0,05\%. Nyamuk Aedes aegypti betina generasi F1 umur 3-5 hari dimasukkan ke dalam tabung susceptibility dan dikontakkan cypermethrin 0,05\% selama 60 menit. Berdasarkan hasil suceptibility test di empat lokasi penelitian disimpulkan bahwa status kerentanan nyamuk Aedes aegypti di tiga desa/kelurahan (Purbalingga Lor, Penaruban, Sempor Lor) adalah resisten (kematian nyamuk uji <80\%), sedangkan status kerentanan nyamuk di Kelurahan Kembaran Kulon adalah toleran dengan tingkat kematian nyamuk uji 81\% (8).

Hasil analisis bivariat. Tabel 4 menunjukkan variabel sikap dan perilaku bermakna secara statistik terhadap status kerentanan Aedes aegypti di lokasi penelitian. Variabel sikap positif dengan PR 0,55 (95\% CI 0,37-0,80) dan variabel perilaku menggunakan 
insektisida rumah tangga dengan nilai PR 1,24 (95\% CI 1,05-1,47).

Tabel 4. Hasil analisis bivariat hubungan perilaku penggunaan insektisida dengan status kerentanan nyamuk Aedes aegypti

\begin{tabular}{|c|c|c|c|c|c|c|}
\hline \multirow{3}{*}{ Variabel } & \multicolumn{4}{|c|}{ Status kerentanan } & \multirow{3}{*}{$\begin{array}{c}\text { PR } \\
(95 \% \text { CI) }\end{array}$} & \multirow{3}{*}{$\mathbf{p}$} \\
\hline & \multicolumn{2}{|c|}{ Resisten } & \multicolumn{2}{|c|}{ Toleran } & & \\
\hline & $\mathbf{n}$ & $\%$ & $\mathbf{n}$ & $\%$ & & \\
\hline \multicolumn{7}{|l|}{ Pengetahuan } \\
\hline Kurang & 38 & 73,08 & 14 & 26,92 & 0,96 & 0,717 \\
\hline Baik & 142 & 75,53 & 46 & 24,47 & $(0,80-1,16)$ & \\
\hline \multicolumn{7}{|l|}{ Sikap } \\
\hline Positif & 15 & 44,12 & 19 & 55,88 & 0,55 & 0,000 \\
\hline Negatif & 165 & 80,10 & 41 & 19,90 & $(0,37-0,80)$ & \\
\hline \multicolumn{7}{|l|}{ Perilaku } \\
\hline Menggunakan & 120 & 81,08 & 28 & 18,92 & 1,24 & 0,005 \\
\hline $\begin{array}{l}\text { Tidak } \\
\text { menggunakan }\end{array}$ & 60 & 65,22 & 32 & 34,78 & $(1,05-1,47)$ & \\
\hline
\end{tabular}

Hasil analisis multivariat. Terdapat dua variabel yang memenuhi syarat untuk dianalisis secara multivariat yaitu sikap positif responden dan perilaku responden dalam menggunakan insektisida.

Tabel 5 Hasil analisis multivariat hubungan sikap dan perilaku penggunaan insektisida dengan status kerentanan nyamuk Aedes aegypti

\begin{tabular}{lccc}
\hline \multicolumn{1}{c}{ Variabel } & $\begin{array}{c}\text { adjusted } \\
\text { PR }\end{array}$ & CI (95\%) & p \\
\hline $\begin{array}{l}\text { Sikap positif } \\
\text { Perilaku }\end{array}$ & 0,55 & $0,38-0,81$ & 0,002 \\
$\begin{array}{l}\text { menggunakan } \\
\text { insektisida }\end{array}$ & 1,22 & $1,04-1,43$ & 0,013 \\
\hline
\end{tabular}

Pada uji kolinearitas tidak ditemukan hubungan yang kuat antar variabel bebas, karena tidak ada satupun variabel yang memiliki nilai $R$-square $>0,9$, nilai tolerance $<0,1$, dan nilai VIF $>10$. Hasil analisis menunjukkan bahwa perilaku menggunakan insektisida di rumah tangga memengaruhi tingkat resistensi nyamuk Aedes aegypti di 4 wilayah endemis di Kabupaten Purbalingga.

\section{BAHASAN}

Hubungan pengetahuan responden dengan status kerentanan. Hasil analisis bivariat menunjukkan hubungan yang tidak bermakna secara statistik antara variabel pengetahuan responden dengan peningkatan status kerentanan nyamuk Aedes aegypti dengan nilai PR 0,96 (95\% CI 0,80-1,16), p value 0,717. Hasil tersebut menunjukkan hubungan antara kedua variabel lemah.

Pengetahuan seseorang dipengaruhi faktor internal (pendidikan, pekerjaan, umur) dan faktor eksternal (lingkungan, sosial budaya). Menurut Nursalam, faktor pendidikan dapat memengaruhi perilaku seseorang akan pola hidup sehari-hari yang dilakukan, termasuk dalam perilaku penggunaan insektisida rumah tangga. Susanti menyatakan bahwa pengetahuan masyarakat di Kecamatan Tingkir Kota Salatiga tidak memengaruhi perilakunya dalam menggunakan insektisida rumah tangga sehingga mempercepat timbulnya resisten pada nyamuk, sedangkan Wigati menyatakan bahwa pengetahuan masyarakat di Kelurahan Kutowinangun memengaruhi perilaku masyarakat dalam menggunakan insektisida rumah tangga (9). Pengetahuan masyarakat yang baik tidak memengaruhi perilakunya dalam pengendalian DBD. Pengendalian vektor nyamuk yang dilakukan masyarakat cenderung menggunakan obat anti nyamuk bakar (70,90\%), hal tersebut telah meningkatkan kerentanan terhadap nyamuk (10).

Pengetahuan baik masyarakat di empat desa Distrik Kuala Kangsar Malaysia telah memengaruhi sikap dalam pencegahan DBD, tetapi tidak memengaruhi perilaku pengendalian. Penggunaan mosquito coils di masyarakat mencapai 74,5\%, sedangkan fogging oleh pihak berwenang mencapai 90,05\%. Hal tersebut menyebabkan nyamuk Aedes aegypti resisten di Kuala Kangsar (11).

Hubungan sikap responden dengan status kerentanan. Penelitian ini menemukan hubungan variabel sikap positif responden dengan status kerentanan. Sikap positif responden memiliki peluang dua kali lebih kecil menyebabkan resisten atau menurunkan 50\% peluang untuk menyebabkan nyamuk menjadi resisten jika dibandingkan dengan sikap positif.

Dalam teori kerangka pikiran sikap menurut Secord dan Backman yang berorientasi pada skema triadik (triadic scheme) disebutkan bahwa sikap merupakan keteraturan perasaan (afeksi), pemikiran (kognisi), dan predisposisi tindakan (konasi) seseorang terhadap aspek di lingkungan sekitarnya (12.) Hasil analisis variabel sikap positif menunjukkan adanya hubungan dengan status kerentanan nyamuk tetapi bersifat protektif terhadap terjadinya resisten, hal ini bisa terjadi karena ketidakseimbangan tiga komponen tersebut.

Penelitian menemukan, masyarakat di Kota Palembang memiliki sikap kurang baik dan mempunyai kemungkinan 1,62 kali berperilaku buruk dalam tindakan pencegahan demam berdarah termasuk dalam pengendalian vektor DBD (13). Ada perbedaan sikap masyarakat di Brazil dan Colombia dalam pengendalian vektor nyamuk Aedes aegypti tahun 2007-2009 yang berpengaruh pada perbedaan keberhasilan dalam pengendalian vektor (14). 
Hubungan perilaku penggunaan insektisida dengan status kerentanan. Golongan insektisida terbanyak yang digunakan adalah synthetic pyrethroids (86,49\%) dengan jenis terbanyak berupa obat anti nyamuk bakar (47,97\%). Synthetic pyrethroids merupakan insektisida generasi kedua yang bekerja pada sistem saraf serangga meskipun beberapa diantaranya memiliki perbedaan dan persamaan target utama yang diserang, tetapi sistem saraf serangga sebagian besar sama (15). Pyrethroids sangat beracun terhadap serabut saraf serangga dengan mekanisme kerja terikat pada protein dalam saraf (voltage grated sodium chanel) yang mencegah menutupnya protein secara normal dan menyebabkan rangsangan saraf yang berkelanjutan.

Bahan aktif insektisida rumah tangga dan insektisida program dinas kesehatan memiliki beberapa kesamaan berdasarkan kelompok senyawa kimianya, cara masuk insektisida (mode of entry), dan cara kerja insektisida (mode of action) (16). Hasil analisis variabel perilaku responden menunjukkan adanya hubungan yang bermakna dengan peningkatan status kerentanan nyamuk Aedes aegypti. Perilaku responden yang menggunakan insektisida memiliki kemungkinan 1,2 kali lebih besar memengaruhi terjadinya resisten pada nyamuk Aedes aegypti dibandingkan responden yang tidak menggunakan insektisida.

Faktor penyebab terjadinya kerentanan Aedes aegypti di daerah endemis adalah akibat tingginya perilaku pemakaian insektisida rumah tangga (17). Dampak dari penggunaan insektisida secara terus menerus yang dilakukan oleh program maupun oleh masyarakat di Kota Cimahi telah menyebabkan Aedes aegypti resisten terhadap cypermethrin 0,2\% dan 0,4\% (18). Resisten terhadap pyretroids pada Aedes aegypti di kota-kota wilayah timur laut Brazil menyebar setelah digunakannya cypermethrin selama 10 tahun. Perbedaan status kerentanan di kota-kota wilayah timur laut Brazil dengan kota-kota wilayah tenggara Sau Paulo sesuai lama penggunaan insektisida cypermethrin (19). Perilaku penggunaan insektisida syntetic pyretroids dalam jangka waktu lama menyebabkan resisten pada nyamuk (20).

\section{SIMPULAN}

Perilaku respoden dalam menggunakan insektisida berhubungan secara statistik dan bermakna dengan meningkatnya status kerentanan nyamuk Aedes aegypti. Responden yang menggunakan insektisida memiliki kemungkinan 1,2 kali lebih besar memengaruhi terjadinya resisten dibandingkan responden yang tidak menggunakan insektisida. Hasil susceptibility test menunjukkan nyamuk Aedes aegypti dari Kelurahan Purbalingga Lor, Desa Penaruban, dan Desa Sempor Lor telah resisten terhadap insektisida cypermethrin 0,05\%, sedangkan nyamuk Aedes aegypti dari Kelurahan Kembaran Kulon masih toleran.

Perlu rotasi penggunaan insektisida program dan rumah tangga menggunakan insektisida dengan mode of action yang berbeda. Penyuluhan kesehatan kepada masyarakat tentang penggunaan insektisida rumah tangga terkait dengan pemilihan bahan aktif, dosis, cara aplikasi dan penggantian secara berkala.

\section{Abstrak}

Tujuan: Penelitian ini bertujuan untuk mengetahui hubungan perilaku penggunaan insektisida dengan status kerentanan nyamuk Aedes aegypti dan mengetahui gambaran kerentanan nyamuk dari daerah endemis di Purbalingga. Metode: Penelitian explanatory research rancangan cross-sectional pada Januari-April 2017 di empat desa atau kelurahan endemis Purbalingga. Sebanyak 240 responden dilibatkan dalam penelitian. Sampel dari tiap desa ditentukan dengan purposive sampling. Pada rumah tangga yang terpilih dilakukan pemasangan ovitrap dan wawancara menggunakan kuesioner. Gambaran status kerentanan nyamuk berdasarkan hasil uji bioassay standar WHO. Hasil: Hasil susceptibility test menunjukkan Aedes aegypti dari tiga desa/kelurahan endemis (Purbalingga Lor, Penaruban, Sempor Lor) telah resisten, sedangkan nyamuk dari Kelurahan Kembaran Kulon masih toleran terhadap cypermethrin 0,05\%. Variabel yang berhubungan dengan status kerentanan nyamuk Aedes aegypti adalah sikap positif responden dan perilaku respoden menggunakan insektisida. Simpulan: Perilaku penggunaan insektisida yang tidak tepat berhubungan dengan peningkatan status ke- rentanan nyamuk Aedes aegypti dan menjadi faktor risiko terjadinya resisten. Perlu rotasi penggunaan insektisida dan rumah tangga menggunakan insektisida dengan mode of action yang berbeda. Penyuluhan kesehatan masyarakat tentang penggunaan insektisida, pemilihan bahan aktif, dosis, cara aplikasi dan penggantian berkala insektisida.

Kata kunci: status kerentanan; Aedes aegypti: insektisida: perilaku 


\section{PUSTAKA}

1. Kemenkes, R.I., Pedoman pengendalian demam berdarah dengue di Indonesia. Dirjen P2P\&PL, Jakarta;2013.

2. Depkes, R.I. Pencegahan dan pemberantasan demam berdarah dengue di Indonesia. Dirjen P2PL, Depkes RI, Jakarta; 2010.

3. Notoatmodjo, S. Pendidikan dan perilaku kesehatan. Rineka Cipta, Jakarta;2003.

4. Georghio, G.P., Melon R.B. Pest resistance to pesticides. Plenum Press, New York;1983.

5. Kemenkes, R.I., Pedoman survei entomologi demam berdarah dengue dan kunci identifikasi nyamuk Aedes. Dirjen P2P\&PL, Jakarta;2013.

6. Wawan, A., Dewi, M. Teori dan pengukuran pengetahuan, sikap, dan perilaku manusia. Nuha Medika, Agustus 2010, Yogyakarta;2010.

7. Azwar, S. Sikap manusia teori dan pengukurannya. Edisi ke-2, Agustus 2016, Pustaka Pelajar Yogyakarta;2016.

8. Macoris, M.D.L.D.G., Andrighetti, M.T.M., Nalon, K.D.C.R., Garbeloto, V.C., Junior, A.L.C. Standardization of bioassays for monitoring resistance to insecticide in Aedes aegypti. Dengue Bulletin 2005(29).

9. Wigati, R.A., Susanti, L. Hubungan karakteristik pengetahuan, dan sikap dengan perilaku masyarakat dalam penggunaan anti nyamuk di Kelurahan Kutowinangun. Buletin Penelitian Kesehatan Vol.40, No.3, 2012:130-141.

10. Yboa, B.C., Labrague, L.J. Dengue knowledge and preventive among rural residents in Samar Province Philippines. American Journal of Public Health Research, 2013, Vol.1, No.2, 47-52

11. Hairi, F., Ong, C.H.S., Suhaimi, A., Tsung, T.W., Ahmad, M.A., Sundaraj, C., Soe, M.M. A knowledge, attitude and practices (KAP) study on dengue among selected rural communities in the Kuala Kangsar district. Asia Pac J Public Health 2003, 15:37-43.

12. Secord, P.F., Backman, C.W. Social psychology. New York: McGraw-Hill Book Company;1964

13. Santoso, Budiyanto, A. Hubungan pengetahuan sikap dan perilaku masyarakat terhadap vektor DBD di Kota Palembang Provinsi Sumatera Selatan. Jurnal Ekologi Kesehatan 2008;7(2): 732-739.

14. Santos, S.L.D., Henao, G.P., Silva, M.B.C., Augusto, L.G.D.S. Dengue in Brazil and Colombia: a study of knowledge, attitide, and practice. Revista da Sociedade de Medicina Tropical 2014;47(6):783-787.

15. Trisyono, Y.A. Insektisida pengganggu pertumbuhan dan perkembangan serangga. Gadjah Mada University Press, Yogyakarta; 2014.

16. Raini, M. Tinjauan kebijakan pestisida rumah tangga. Buletin Penelitian Sistem Kesehatan Vol.12 No.2 April 2009: 187-194.

17. Sunaryo, Astuti, P., Widiastuti, D. Gambaran pemakaian insektisida rumah tangga di daerah endemis Kabupaten Grobogan tahun 2013. Jurnal Litbang Pengendalian Penyakit Bersumber Binatang Banjarnegara (BALABA) 2015;11(1):9-14.

18. Pradani, F.Y., Ipa, M., Marina, R., Yuliasih, Y. Status resistensi Aedes aegypti dengan metode Susceptibility di Kota Cimahi terhadap Cypermethrin. Aspirator 2011;3(1): 18-24.

19. Macoris, M.D.L.D.G., Andrighetti, M.T.M., Otrera, V.C.G., Carvalho, L.RD., Junior, A.L.C., Brogdon, W.G. Association of insecticide use and alteration on Aedes aegypti susceptibility status. Mem Inst Oswaldo Cruz, Rio de Janeiro 2007;102(8):895-900.

20. Andiarsa, D., Sembiring, W.S.R.G. Perilaku penggunaan insektisida pada rumah tangga di tiga Kabupate/Kota Provinsi Sulawesi Selatan. Jurnal Epidemiologi dan Penyakit Bersumber Binatang (BUSKI) 2015;.5(3):149-154. 
Berita Kedokteran Masyarakat, Volume 33 No. 10 Tahun 2017 